respiratory movements may continue for a while, even though the air-way be quite occluded. The obstructed breathing produced by pure nitrous oxide appears to have as its immediate cause spasm of muscles capable of closing the superior opening of the larynx. The spasmodic action of these muscles takes place in conjunction with the contraction of other muscles throughout the body. If the hand be placed over the larynx of a person deeply under the influence of pure nitrous oxide the whole organ will usually be found to be spasmodically raised as in the first half of the act of deglutition, and when it is thus drawn up so that its superior aperture becomes closed by the epiglottis and base of the tongue respiration ceases. It would be premature to attempt to specify the muscles which contribute to the occlusion of the larynx. The point which I would emphasise is that arrested breathing under nitrous oxide is almost invariably obstructive and is rarely, if ever, dependent upon respiratory paralysis.

It will, I think, be clear from the above considerations that although nitrous oxide is the safest general anæsthetic known there are certain cases in which it is distinctly dangerous. Some years ago a well-known writer on the subject of anæsthesia read an exhaustive paper on the physiological action of this gas and, in his zealous advocacy of its safety and universal applicability, went so far as to deny that it was an asphyxiant. Now, teaching of this kind can only have effects such as we find in Dr. Dent's case, and the sooner its fallacies are recognised the better will it be for all concerned. I do not for one moment deny that in the hands of those who have had special experience pure nitrous oxide is a safe anæsthetic, even though its administration be pushed to the point of arrested breathing. But like other drugs it is not suitable in all types of subjects. To state that the pure gas is not an asphyxiant is, I venture to think, a most misleading doctrine. Fortunately our present knowledge enables us to disprove this assertion, but it will, $I$ fear, be some time before the truth becomes universally accepted.

It is a matter for congratulation that at the present time we have reliable means at our disposal for obtaining nitrous oxide anæsthesia free from unnecessary asphyxia. This can be accomplished by administering the gas with proper percentages of oxygen. By this system the one disadvantage of nitrous oxide is eliminated and we have at our command an anæsthesia so safe that it is difficult to conceive any fatality arising during its maintenance.

I am, Sirs, yours faithfully, FREDERIC HEWIT'T.

Queen Anne-street, Cavendish-square, W., April 11th, 1899.

\section{WHERE SHALL WE BUILD OUR NATIONAL SANATORIA FOR CONSUMPTIVES?}

\section{To the Editors of THE LANCET.}

SIRs,-The interest in the open-air treatment of phthisis which has been stimulated by the propaganda of the Association for the Prevention of Consumption and Other Forms of Tuberculosis and the proposals to establish sanatoria in this country have already had one useful result in drawing attention to the possibility of successfully treating this disease in such a climate as that of the British Isles. The conviction is gradually gaining ground that the fresh-air treatment may be successfully carried out without sending the patient out of England. This is important, for the majority of phthisical patients are unable to afford the expense or to stand the fatigue of visiting foreign health resorts. The influence of climate in the causation of phthisis, once considered paramount, is now given a secondary place; and though our variable climate is still considered by many as an obstacle to successful treatment we may sanguinely expect within a very few years to find this idea less prominent. True, our climate is not the most suitable that is to be found, but " "twill serve." Hitherto the treatment of phthisis at home has been considered so nearly hopeless by the public, if not by the medical profession, that systematic attempts at cure have never reached the completeness obtaining in many foreign sanatoria. That success is possible without leaving our own shores is known to most of those who have much experience in the treatment of phthisical cases, but as a rule we have advised our patients to change their locality with the changes of season and in this country of many climates-or as has been said of climatic "samples"-to chase the sunshine from place to place. The proposal to erect sanatoria must, however, direct our attention to the selection of such parts of the country as will be most suitable for all-round residence-districts where phthisical subjects may be able to live in the open air all the year round with the maximum of sunshine and the minimum of rain. All cases are not alike in their climatic requirements, and just as some are benefited by the warmth of Egypt and others by the bracing cold of the Engadine altitudes, so will different localities in this country have their several claims to selection as sites for sanatoria. But whether we seek for comparative warmth or for bracing uplands, dryness of soil and air with a maximum of sunshine throughout the year must be considered as essential.

Before any large sanatoria such as are proposed in the scheme of the Association for the Prevention of Consumption can be commenced full information as to the climatic advantages of many localities will have to be collected, and I wish to draw attention to a district which has lately attracted my notice from the marked benefit received by a phthisical patient who recently spent some time there. Several well-known health resorts are situated along the southern shore of the Bristol Channel and the climate of that district seems to be peculiarly equable and dry. Portishead shares the advantage of the rest of this district and has in addition characters peculiar to itself. Half an hour by train from Bristol it is easy of access. Rising above the village is a hill some 400 feet high dotted over with residences. The northern slope faces the Channel with the Welsh hills behind Newport in the distance; the southern slope looks across the valley to hills beyond. Towards the east the view extends to the Clifton downs, whilst westwards the Channel leaves free passage for the soft west breeze which is the prevailing wind. Sheltered thus by neighbouring hills from north and east, standing high above the water, and being favoured by an exceedingly clear atmosphere and small rainfall, the hills of Portishead are protected from cold winds and receive an amount of clear sunshine throughout the year which is exceptional. The tide of the Bristol Channel here rises and falls about 37 feet, and perhaps the air currents produced by this large diurnal alteration in the water level may account for the absence of fogs. The Welsh hills seem to attract the clouds and to draw them away from the south side of the Channel. Hill and dale, woods and lanes with fern-grown banks, tempt one to wander in the open air, whilst the sunshine and warm breeze allow of this out-door life without risk. Such is the account given me by residents and visitors and a short visit left me with the impression that they were not exaggerating. The drainage and water-supply are excellent. With these advantages it is not surprising to find statistical evidence that the place is healthy. An average death-rate of 12.35 per 1000 from all causes for the last six years shows a death-rate from phthisis of 1.48 and a zymotic rate of 0.99 per 1000 and $a$ very low rate from pulmonary diseases such as pneumonia, pleurisy, and bronchitis. The fact that many tender and subtropical plants will stand the winter without protection speaks favourably for the temperature. There may be several places with climatic advantages equal to those of Portishead, but there must be few which would be more suitable for a prolonged residence for phthisical subjects seeking health.

I am, Sirs, yours faithfully,

J. EDWARD SQuIRE, M.D. Lond.

Physician to the North London Consumption Hospital, \&c. April 8th, 1899

\section{PREVENTION OF ZYMOTIC DISEASES, To the Editors of THE LANOFT.}

SIRs, - I should like to bring before the medical profession the subject of the prevention of zymotic diseases with a view of making our first line of defence in these diseases much stronger than at present, seeing that the serious consequences which they produce are apt to last for life. I do not consider that we take sufficient precautions to ward off these affections early enough. I have been much struck in treating these diseases with the immediate and marvellous curative results which follow chlorine gargles in scarlet ferer and glycerine and carbolic acid gargles in other zymotic diseases. From the moment they are commenced, while all the "ports" are lept open, the disease is arrested in its progress. Now, knowing all this, are we simply to go on for ever allowing these diseases to develop? I would say, Certainly not. We ought to advance and keep ourselves constantly protected 
against the invasion of the bacteria which cause them. These bacteria attack first our throats and then spread to neighbouring mucous membranes, setting up first irritation, then inflammation and ulceration, followed by poisonous absorption, with all the well-known clinical symptoms. Therefore I would advise all parents, guardians, and especially masters and mistresses of scholastic boarding houses, to see that the young people attending school have their throats thoroughly and regularly gargled or sprayed with an antiseptic morning and evening, so that if they did come in contact with infection this timely care would keep them free from danger. I have no hesitation in saying that if these directions were faithfully carried out they would go a long way to simply and effectually prevent these diseases. The trouble of doing all this would be amply rewarded by relief from great anxiety, not to speak of the great waste of time and money lost while the rising generation were being educated.

Cheltenham. I am, Sirs, yours faithfully,

J. WILsoN, M.D. Edin.

\section{THE INFLUENCE OF CLIMATE IN THE TREATMENT OF PHTHISIS.}

\section{To the Editors of THE LANCET.}

SIRS,-Although Davos has probably had more phthisical patients in it than any other health resort in the world during the last 25 years, yet the scientific literature dealing with the medical aspects of the "cure" there and the statistics there are very limited. Herr Hofrath Dr. Turban's book "Beiträge zur Kenntnis der Lungentuberkulose," which has just appeared, gives some very important facts. It enables Davos to take its place in the comparative statistics which are of such great service in determining the respective merits of rival resorts and methods.

In Tngland it is being asserted again and again that climate has nothing or very little to do with the cure and patients are told that they can be cured just as well in England as in the high Alps. The new evidence is very much against this pleasant idea. Dr. Turban shows that during seven years 66.1 per cent. of all the patients treated in the sanatorium over which he presides were absolutely or relatively cured-i.e., were discharged in a normal state of health, and that from one to seven years after their discharge 48 per cent. still retained this state of health. Of patients in the third stage with extensive and serious disease of the lungs 17.4 per cent. were permanently cured, while of those in the first stage with only slight tuberculosis in one lung 97.5 per cent., or almost all, were permanently cured. At Falkenstein, the best known of the German lowland sanatoria, we find the number of absolute and relative cures given as 24.2 per cent., or (according to Meissen's statistics) the permanent cures were only 22 per cent.-i.e., less than half the number obtained at Davos.

That these results are obtained not only in closed sanatoria at Davos is shown by the statistics of Dr. Lucius Spengler for the years 1887-90, when 41.8 per cent. of the patients treated by him were absolutely and relatively cured-i.e., nearly twice as many as at Falkenstein. Those of us who have personally experienced the curative effect of the Davos climate are glad to see its great value thus scientifically demonstrated.

I am, Sirs, yours faithfully,

EDWARD H. DOUTY, M.A., M.D. Cantab. Davos Platz, April 7th, 1899.

\section{"DIFFICULTIES UNDER THE NEW VACCINATION ACT."}

\section{To the Editors of THE LANCET.}

SIRs,-I do not wish to appear to "fight shy" of this correspondence and with your kind. permission I will reply to "P. P.'s" letter in The LANCET of March 25th although Mr. Blaker's letter of the same date anticipates my answer concisely and well. I am using Messrs. Burroughs and Wellcome's visiting list which I believe has been brought to its present stage of usefulness by the proprietors obtaining hints from many members of the profession. Why should a column for vaccination cases be placed amongst the obstetric engagements if my opinion is incorrect? Surely, it could have been entered in the ordinary part of the book. There is a vast deal of difference between calling on a patient whom you have heard is enceinte to offer your services and suggesting the advisability of having a child vaccinated whose mother you have attended when it was born, which attendance (generally speaking) makes you the medical attendant of the child.

If "P. P." noticed that an infant whom he had lately brought into the world was suffering from one of the following conditions-viz., hernia, a rapidly growing nævus in the neighbourhood of the eye, glioma of the retina, \&c., or that ophthalmia neonatorum came on severely after a few daysI suppose it would be very unprofessional for him to warn the mother and to suggest treatment in any way, as it would be for him to try to save his little patient against an attack of small-pox. I have had people complain to me ere now bitterly of the professional etiquette they have been subject to and I think that they have had just cause if they have encountered a similar practitioner to what "P. P.," perhaps unworthily, makes himself out to be. True medical etiquette should not be only a boon to the practitioner but an equal one to the patient. But whether I am right or wrong in my views there is no getting over the fact that the parent and practitioner between them after having large opportunities must ignore the law before any public vaccinator will bother them and therefore they are primarily at fault and it is a noble way to get out of the difficulty by blaming the public vaccinator.

March 28th, 1899. I am, Sirs, yours faithfully,

\section{AN IMPORTANT POINT UNDER THE INFECTIOUS DISEASES (NOTIFICA- TION) ACT. \\ To the Editors of THE LANCET.}

SIRS, - I shall esteem it a great favour if you will advise me how to proceed in the following case. I rendered my account to our urban council for the notification of infectious diseases cases which I had reported during the year 1898 and got a reply from their clerk informing me that he had been instructed by the council to deduct from my account all the cases which $I$ had reported during the first six months, as the council cannot pay debts which have been contracted more than six months before the making of the last general district rate-viz., on Oct. 28th last-and enclosing a cheque for the remainder of my account. Can I lawfully claim or demand payment for the first six months, or can I lawfully refuse to report further cases until my account is paid in full?

April 12th, 1899.

I am, Sirs, yours faithfully M.B., O.M.

* * The case submitted to us is by no means free from difficulty. Under the Public Authorities Protection Act, 1893, it is provided by Section $1(a)$ as follows:- "The action, prosecution or proceeding shall not lie or be instituted unless it is commenced within six months next after the act, neglect, or default complained of ......;" and it is probably on this that the urban district council refuse to pay fees for notifications sent in on or before the termination of October, 1898. But it might be argued that since the notifications were sent in to the medical officer of health and not to the urban district council, the debt on the part of the council did not arise when the notification forms were sent in, but only when a summary of the amount due for them was transmitted to the clerk to the urban council, and that as six months have not elapsed since the debt became due it is still open to the medical practitioner to proceed for peyment of the debt due to him. Action on these lines should, however, be based on legal advice. On the other hand, the urban council might be urged not to stand upon the strict letter of the law as interpreted to them by their legal adviser on the ground that if they paid a claim which was so obviously just, and if by chance it were surcharged by the auditor, the surcharge would certainly be remiteed by the Local Government Board. Payment might perhaps be accepted on condition that the amount would be refunded if $\mathrm{su}$. $\mathrm{h}$ surcharge were not remitted.-ED. L. 